\title{
Grzegorz Wạchol
}

ORCID: https://orcid.org/0000-0002-6427-7231

The Pontifical University of John Paul II in Krakow, Poland

\section{Pastoral Communities Based on a Model of Self-Help Groups as a Response of the Church to the Contemporary Social Changes}

\begin{abstract}
Dynamic changes in modern society generate new situations in the lives of believers, which require pastoral care. The Church should respond to the spiritual needs of all those in need, but with the decreasing number of ordained priests in Europe, organizational capacity in this part of the world is becoming increasingly limited. This article is an attempt to respond to the above problems and, using the example of the Catholic Church in Poland, shows the possibility of instilling a model of self-help groups for specialist pastoral care involving people experiencing life crises and wanting more intense religious development.
\end{abstract}

\section{Keywords}

Pastoral communities, Needs of pastoral care, Social changes, Self-help group. 


\section{Introduction}

The Catholic Church as a dynamic reality develops in multidimensional ways. A mature description of any development assumes not only constant growth in a particular area but also it considers this phenomenon for qualitative changes, the differences in its increase, accumulation of another forms or indeed the loss of present forms or even quantitative decline.

To maintain the efficiency or continuity of a particular action a skilful study of changes which occur through this action is needed, a historical analysis taking into consideration reasons of any observed transformation, or the attempt to formulate conclusions which allow the modification of the present forms, appropriately to new conditions.

The Basic space in the Church, which is most exposed to the influence of temporal factors is pastoral work. At its core lies the Gospel but the way of its transmission can be changed in relation to the environment and era in which it occurs. The present article is an attempt to respond to the needs of development of new forms of pastoral work in a few areas of actions in the Catholic Church in Poland. The situation, in which the decline of vocation to the priesthood or the growth of demand of special pastoral work occurs, forces the reorganization of some pastoral structures. A model for some of these needs can be self-help groups which are increasingly becoming more effective in Poland. Instilled into the church environment in a right way they can contribute to build a new pastoral model.

\section{Social changes in Poland as factors of changes in pastoral work}

The turn of the 2oth and 21st centuries became time of rapid social changes in Poland. After regaining freedom on a political dimension, the people also started searching personal freedom. John Paul II, in his proclamation for the International Day of Peace in 1981, compared a free person to an artist who gradually sculpts one's masterpiece and gives a shape to one's lives, always moving forward into the unknown which awaits them in the future. ${ }^{1}$ Each person

Jan Paweł II, Chcesz służyć sprawie pokoju - szanuj wolność. Orędzie na Międzynarodowy Dzień Pokoju 1981 r., in: P. Nitecki, J. Skwara, W. Szymanek (eds.), Jan Paweł II, Nauczanie społeczne. T. IV, Warszawa 1984, wyd. Ośrodek Dokumentacji i Studiów Społecznych, no. 11. 
strives to be free, and this is the basic right of a human being, but it is relatively easy to mistake freedom for self-will. ${ }^{2}$

In the social changes that occurred in last years in Poland one can observe the choice of false facets of freedom which, in time end up in enslavement rather than giving a sense of independence. One of the signs is an increase of traditional addictions known for years such as alcoholism, drug addiction, medicament dependence, or new addictions connected with the compulsive use of electronic devices, oniomania (shopaholism) or sexual addictions. ${ }^{3}$ These kinds of problems are becoming more common, and independently from the kind of addiction, they affect, not only the person addicted directly but also the whole environment of the addict - the family, the neighbourhood, colleagues, acquaintances or even strangers who are merely affected by the social and financial costs of this phenomenon. ${ }^{4}$ Addictions destroy a value system, the sense of human dignity sense, undermine family bonds and the personal attitude to God. ${ }^{5}$ Thus, in the congregation of the faithful we face new categories of people - addicted or co-addicted who demand specialist pastoral support.

One also observed radical changes in the work patterns, and forcing workers to a higher competence and flexibility. There are also new ways of virtual communication and the development of new technologies and devices. Legal articles are changing causing the urgency of acquiring new knowledge and new skills. As a result of such dynamics, the contemporary person is more often exposed to a higher level stress, has no enough time at one's disposal or is overworked. This all has serious consequences such as the weakening of interpersonal relations, more focus on one's own needs, a change in the value system, a materialistic or survival mode of being or sometimes a great disorder

2 J. Tischner, Etyka solidarności, Kraków 1981,wyd. Znak, p. 49.

3 C. Davies, J. C. Carter, Compulsive overeating as an addiction disorder. A review of theory and evidence, "Appetite" 53 (2009), pp. 1-8; B. Wojtyniak i P. Goryński, Sytuacja zdrowotna ludności Polski i jej uwarunkowania, Warszawa 2008, wyd. Państwowy Zakład Higieny, p. 190192; M. Cichońska, W. Nartowska, D. Kaczmarzyk, S. Szemraj, G. Mazur, Tendencje w zakresie spożywania alkoholu, „Acta Scientifica Academiae Ostroviensis” 1 (2013), pp. 199-200.

4 L. Møller. S. Matic, Best practice in estimating the costs of alcohol-Recommendations for future studies, Copenhagen 2010, wyd. WHO Regional Office for Europe, pp. 13-19, 43-45.

5 M. Eliason, D. S. Amodia, C. Cano, Spirituality and Alcohol and Other Drug Treatment: The Intersection with Culture, "Alcoholism Treatment Quarterly" 24 (3) (2006), pp. 121-141. 
in one's life. ${ }^{6}$ These people demand spiritual care which is appropriate to their needs and to the way of understanding the world which slowly lets them find God and open to the metaphysical sphere. Better quality of medical care and longer length of life causes the increase in number of old people, often lonely, especially when their spouse die. In 2018, in the Polish society, almost every fourth person was sixty years old.' This intensifies the loneliness of senior citizens who often have no contact with the members of the closest family because of the generation disintegration. The older people who have more time at their disposal need to manage time in a smart way, especially in the context of coming reality of the end of their life, which bring about obvious higher spiritual needs. These are other groups of persons who can be involved in supporting other groups needing pastoral care.

The next visible phenomenon characteristic for the last years is migration which is reaching still higher levels. People migrate for different reasons: to earn money, to further their education or to protect their lives by fleeing areas threatened with war. ${ }^{8}$ Even by merely distinguishing these three groups of migrants highlights their with separate specific pastoral needs especially when they are living outside their homeland. In Poland, the majority of immigrants are the citizens from the Ukraine, Belarus and countries in South-East Asia who often profess the Catholic faith and seek spiritual care. ${ }^{9}$

The level of education in Poland also changed. In the last half century the number of graduates of universities in a given year increased by nine times and presently it is at the level of 350,000 yearly, within the greatest increase noted after the year 2000. ${ }^{10}$ Presently, on average every fifth Polish citizen has got a university or higher education. ${ }^{11}$ The Church should be able to respond to these changes and provide pastoral work which is more deeply intellectual,

${ }^{6}$ I. Pekarskiene, R. Susniene, The Assessment of the Manifestation of Economic Globalization: The International Trade Factor, "Procedia - Social and Behavioral Sciences" 156 (2014), pp. 392-397.

https://www.populationpyramid.net/pl/polska/2018/ (17.03.2020).

8 https://ec.europa.eu/eurostat/statistics-explained/pdfscache/1275.pdf (17.03.2020).

9 E. K. M. Hounaké, Duszpasterstwo migrantów na przykładzie działalności Werbistowskiego Centrum Migranta Fu Shenfu, „Nurt SVD” 1 (2018), pp. 151-166.

10 Sz. Czarnik, K. Turek, Aktywność zawodowa i wykształcenie Polaków, Warszawa 2014, wyd. Polska Agencja Rozwoju Przedsiębiorczości, p. 67.

11 Sz. Czarnik, K. Turek, Aktywność zawodowa i wykształcenie Polaków, Warszawa 2014, wyd. Polska Agencja Rozwoju Przedsiębiorczości, p. 60. 
bringing the faith closer to people with a higher education. The changes are observed as well in the family structures. Young people are delaying the moment of starting their own family, many of them living as singles since they put their career before planning marriage and having children.

A relatively new phenomenon is also cohabitation or civil marriage formalized only by civil law or even without that. The rate of divorce has increased, in the last forty years in Poland - there are twice more cases of divorce than previous years. ${ }^{12}$ This leads to secondary relationships which are visible in patchwork families where family ties are more extended but could be shallower. ${ }^{13}$ Consequently these transformations cause greater loneliness within people and spiritual emptiness, leading to a search for meaning in life, discovering one's personal vocation and Divine Providence's action in life. ${ }^{14}$

The last clearly visible change in Polish society is liberalism especially in the area of sexual ethics which affects young people strongly. The age of sexual initiation is gradually declining, generally using pornography (every underage fifth girl and every under age fourth boy), including sexting, which means sharing erotic content with their own participation, prostitution of minors or casual sex. ${ }^{15}$ The redefinition of the sexual sphere, especially at a young age can lead to addiction to this type of behaviour, to a lack of skills necessary to build healthy relations with other people and above all, departure from the faith and the loss of opportunities to reach a final goal meant as a union with God. ${ }^{16}$

${ }^{12}$ CBOS, Stosunek Polaków do rozwodów - komunikat z badań, Warszawa 2019, wyd. CBOS, p. 1.

${ }^{13}$ B. J. Willoughby, J. S. Carroll, D. M. Busby, The different effects of "living together": Determining and comparing types of cohabiting couples, "Journal of Social and Personal Relationships" 29 (3) (2011), pp. 397-419.

${ }^{14}$ Sobór Watykański II, Konstytucja Duszpasterska o Kościele w świecie wspótczesnym Gaudium et spes, Wrocław 2005, wyd. TUM, no. 4-10.

${ }^{15}$ J. Lewczuk, Psychologiczne konsekwencje ryzykownych zachowań seksualnych młodzieży, in: M. Z. Jędrzejko, A. Szwedzik (eds.), Pedagogika i profilaktyka społeczna. Nowe wyzwania, konteksty, problemy. Tom I, Warszawa 2018, wyd. ASPRA, pp. 221-245.

${ }^{16}$ G. Krawiec, Czystość jako wartość, „Roczniki pedagogiczne” 43 (2015) 3, pp. 93-114. 


\section{Changes in the Church structures as a factor in the development of pastoral work}

Apart from all these changes observed in society, the Church itself and its structure has undergone many changes too. The most serious change is a decreasing number of the faithful taking part in the Holy Masses on Sunday and their following of the Christian teachings, and a fall in the number of vocations to the priesthood. Both factors urgently demand search for new forms of pastoral work appropriate not only to these social but also ecclesial changes.

In case of the first problem we can observe a gradual decrease of people who participate in the Holy Mass every Sunday (dominicantes) in the Church in Poland. In the last thirty years mass attendance has declined from the level of $50 \%$ to $60 \%$ in relations to the diocese to a bit more than $30 \%$, revealing a slows a downward tendency ${ }^{17}$. It is has also been observed that since 1991 participation in the Sunday Mass is no longer a categorical imperative, but has become optional or not an obligation in the understanding of the faithful. ${ }^{18}$ The research conducted between 1991 and 2012 showed a twofold increase of the quantity of people who don't identify with their own parish community. This makes up one quarter of the population in Poland..$^{19}$ In the named time period one could also observe a decline in the declared daily prayer - ten per cent among believers and each fifth researched in 2012 gave up the prayer on regular basis. ${ }^{20}$ Similar low levels have been observed for declared membership in religious communities, it fluctuates between 7 and $9 \%$ and has not recorded any significant change. ${ }^{21}$ The Poles are moving away from the absolutistic, abstract,

17 http://iskk.pl/badania/religijnosc/211-praktyki-niedzielne-polakow-dominicantes (18.03.2020).

18 J. Mariański, Praktyki religijne w Polsce w procesie przemian, in: L. Adamczuk, E. Firlit, W. Zdaniewicz (eds.), Postawy społeczno-religijne Polaków 1991-2012, Warszawa 2013, wyd. Instytut Statystki Kościoła Katolickiego, p. 97.

19 E. Firlit, Wspólnotowy wymiar religijności, in: L. Adamczuk, E. Firlit, W. Zdaniewicz (eds.), Postawy społeczno-religijne Polaków 1991-2012, Warszawa 2013, wyd. Instytut Statystki Kościoła Katolickiego, p. 135.

20 J. Mariański, Praktyki religijne w Polsce $w$ procesie przemian, in: L. Adamczuk, E. Firlit, W. Zdaniewicz (eds.), Postawy społeczno-religijne Polaków 1991-2012, Warszawa 2013, wyd. Instytut Statystki Kościoła Katolickiego, p. 85, 97.

${ }^{21}$ E. Firlit, Wspólnotowy wymiar religijności, in: L. Adamczuk, E. Firlit, W. Zdaniewicz (eds.), Postawy społeczno-religijne Polaków 1991-2012, Warszawa 2013, wyd. Instytut Statystki Kościoła Katolickiego, p. 144. 
rigorous view in moral matters to the way of thinking in categories of personal experience and seeking for solutions depending on particular life situations. ${ }^{22}$

At the same time, there is an increased percentage of people receiving Holy Communion. In the researched period (1991-2012) the number of people taking this Sacrament (communicantes) increased from a few percent to almost 20 per cent. ${ }^{23}$ At the high unchangeable level is the percentage of people who confess at least a few times a year reaching $75 \%$ at the scale of the whole country. ${ }^{24}$ From less formal sources of information it is assumed that there is gradual development of different religious communities in the area of the Catholic Church in Poland, often founded and organized by lay people. They often form an association of different social categories eager to deepen their bond with God. ${ }^{25}$ It can be assumed that Polish religiosity is still clerical which means strongly built around the Church institutions and focused around priests. ${ }^{26}$ Simultaneously, there is a strong polarisation between those who treat their faith a ritual and experience it as a duty or as a tradition and those who are more engaged and seeking the depth of faith. ${ }^{27}$

The second factor bringing about the most intensive changes in the Church structure is decrease of priestly and monastic vocations which in the close future will generate very serious problems with regards to staff in the Catholic Church in Poland. In the last twenty years the number of newly ordained priests in Poland has fallen by half from about 600 diocesan priests at the beginning of the third millennium to 300 a year presently. The number of all priests in Poland is still stable and it adds up to 23,00o but the decline in consecration of the priests and increased number of priests who have left the priesthood in the $21^{\text {st }}$ century

22 J. Mariański, Religia i moralność w świadomości Polaków - analiza socjologiczna, „Zeszyty Naukowe KUL" 57 (2014), nr 4 (228), p. 72.

${ }^{23} \mathrm{http}: / /$ iskk.pl/badania/religijnosc/211-praktyki-niedzielne-polakow-dominicantes (18.03.2020).

${ }^{24}$ J. Mariański, Praktyki religijne $w$ Polsce $w$ procesie przemian, in: L. Adamczuk, E. Firlit, W. Zdaniewicz (eds.), Postawy społeczno-religijne Polaków 1991-2012, Warszawa 2013, wyd. Instytut Statystki Kościoła Katolickiego, p. 97.

${ }^{25}$ https://opoka.org.pl/biblioteka/D/DS/ruchy_nadzieja_kl.html (18.03.2020).

26 B. Pawłowska, „Polak-katolik” - czyli o religijności wspótczesnych Polaków, „Władza Sądzenia" 6 (2015) 1, pp. 77-92.

${ }^{27}$ W. Sadłon, Differentiation, polarization and religious change in Poland at the turn of 20th and 21st century, "The Religious Studies Review" 262 (2016) 4, pp. 25-42. 
(6o-8o cases a year) suggest that soon there will not be enough priests to cover all Polish parishes. ${ }^{28}$

The changes in the Church structure in the view of the faithful towards religiosity or the staffing situation of priests suggest a need of change in the priesthood model which is appropriate to the needs and opportunities which will exist in next few years.

\section{The origin of self-help groups}

Self-help is a way of supporting action for people who are aggrieved in a given life space, in situations when the help of the specialists is not provided. The essence of self-help groups is the exclusive participation of people with this problem in a context in which they get support. It gives a sense of comfort which emerges from the equality of all members. This form of work support, most often of a socially and psychological nature is a result of mutual attention and the sharing of similar life situations. ${ }^{29}$ Support in self-help groups is based, first of all, on mutual understanding, formulating experienced problems, reflection on the basis of thedepicted narration, discovering the presence of other people with the same experiences, the opportunity for emotional abreaction, drawing on other people's experiences, accepting strategies which turned out to be effective in solving problems by other people, controlling group members by verifying the implementation of the provisions, drawing hope from the other people's example. ${ }^{30}$

This kind of support can be offered to different categories of people mostly those who go through some kind of exclusion e.g. because of addiction, mental health issues, disability, social misunderstandings, a different race or world view. It is one of the oldest form organized probably from the beginning of existing civilisation, and formalised from thirties in the 2oth century when it was used to heal alcoholism by Anonymous Alcoholics (AA). The AA movement is an

28 http://iskk.pl/images/stories/Instytut/dokumenty/ISKK_Ksieza_odejscia.pdf (18.03.2020).

29 T. McLellan, What is recovery? Revisiting the Betty Ford Institute Consensus Panel definition: The Betty Ford Consensus Panel and Consultants., "Journal of Substance Absue Treatment" 38 (2010) 2, pp. 200-201.

30 Meszuge, Krok za krokiem: $z$ alkoholizmem można wygrać!, Kraków 2014, wyd. WAM, pp. 262-264. 
example of very high effective self-help work which appears, first of all, due to a high level of motivation inside the group. ${ }^{31}$ Presently it can be observed through existing groups, meeting either in reality or virtually which are built by electronic tools and different ways of access such as internet forums, instant messaging or social media. Virtual groups are usually less formalized than real groups, they are more spontaneous, unstable in time and often draw people with problems about which it is difficult to talk about during the real face-to-face meeting. An example of such group is the popular internet blog "Angel mums" which brings together women who miscarried their babies. In their opinion this kind of space is a very good form of psychological help ${ }^{32}$.

In the history of AA movement it has been observed that religiosity or spirituality is an important factor in self-help groups. However AA is open to all religions and in principle it constitutes an organization embracing neutral world view but it assumes the necessity trust in God or a power, no matter how this is envisaged by any given participant. ${ }^{33}$ Analysing the self-help system, using the example of AA and in the context of the possibility of instilling this in the pastoral life of the Catholic church, it is necessary to note the danger connected with the image of God. The precursor of AA was is an Oxford Group coming from Swiss Lutheranism, so assuming an image of God characteristic for Protestant confessions, which in key issues is considerably different from the Catholic tradition..$^{34}$

\section{Pastoral communities based on self-help groups}

The current analysis of social changes in Poland in the space of the last years or problems related to the transformation within the Church structure reveals

31 D. Q. Luong, Corsini Encyclopedia of Psychology, V. 4, Hoboken 2010, wyd. Wiley \& Sons, pp. 1538-1540; W. Pańków, Słownik metod technik i form pracy socjalnej opiekuńczej i terapeutycznej. Tom 3, Opole 2014, wyd. Uniwersytetu Opolskiego, p. 36. Grupa AA, Dwanaście kroków i dwanaście tradycji, Warszawa 2017, Wydawnictwo: Fundacja Biuro Służby Krajowej Anonimowych Alkoholików w Polsce, pp. 17-18.

M. Wojaczek, Aniołkowe mamy, Kraków 2009, wyd. M, pp. 8-16.

33 Alcoholics Anonymous, The twelve steps and twelve traditions, New York 2005, wyd. Alcoholics Anonymous World Services, pp. 34-42.

${ }^{34}$ M. Wnuk, Duchowy charakter Programu Dwunastu Kroków a jakość życia Anonimowych Alkoholików, „Alkoholizm i Narkomania” 20 (2007) 3, pp. 289-301. 
the need of development of pastoral work in the near future. The direction of this development should be organized in such a way that Church work can effectively reach out to people who are affected by contemporary social problems, simultaneously taking into account a decrease in the number of priests. ${ }^{35}$ Having a coherent vision of pastoral work allows us to define the precise implications of its demands. Effectiveness, in this case, should lead to a mature administration of the Church sacraments and its fruits and not exclusively multiplying the numbers of those engaged in pastoral work. ${ }^{36}$

The effectiveness of therapeutic self-help groups comes through being in touch with people who have similar experiences their lives. Hence the first element which can be instilled pastoral work based on the notion of self-help is to create communities in which members bond with each other through a common feature in their life situation. This form of pastoral could be considered as in special ministry. ${ }^{37}$ The common feature does not have be problematic in nature as in the case of self-help actions, however persons who are weighed down by some problems also need pastoral support. Each negative experience affects the spiritual life of the person going through it. ${ }^{38}$ Apart from the psychological benefits emerging from the spiritual formation in a community, the main aim should be always opening to an increasingly more mature contact with God.

The inner structure of pastoral communities adopting the model of self-help groups should be extremely easy because they will underline the dignity and equality of each of the members. The leaders' actions should be limited to organization matters such as connecting with care about preparing a meeting, its topic, a place and a date. Such an attitude is also a guarantee to keep the aim which is forming the faith of participants and not promotion of a particular person. ${ }^{39}$

The content of the meetings leading necessary for formation should be tailor made according to the specific and more important needs of a particular

${ }^{35}$ Sobór Watykański II, Dekret o pasterskich zadaniach biskupów w Kościele Christus Dominus, in: M. Cholewa, Sz. Dżyżdżyk, M. Gilski (eds.), Sobór Watykański II: złoty jubileusz, Kraków 2013, wyd. Scriptum, no. 16.

${ }^{36}$ K. Koch, Die Kirche Gottes, Trier 2007, Paulinus Verlag, pp. 220-221.

37 R. Kmiński, Wprowadzenie, in: R. Kaminski, B. Drożdż (eds.), Duszpasterstwo specjalne, Lublin 1998, wyd. KUL, pp. 13-19.

${ }^{38}$ W. Durda, Chrześcijańska postawa wobec cierpienia, Kraków 1998, wyd. Znak, p. 50.

${ }^{39}$ R. Biel, Duszpasterstwo w kontekście paradygmatów czasu przełomu, in: R. Chałupniak, J. Kostorz (eds.), Współczesne wyzwania teologii pastoralnej, Opole 2016,wyd. Wydziału Teologicznego UO, pp. 67-76. 
community. To identify such a content, an analysis of the value system of participants and the most serious needs in the aspect of faith would first need to be carried out. Very important issues include work on one's image of God and, knowledge about the Church and its interaction with a contemporary world. It concerns, first of all, people who are clearly spiritually weak. In the case of people experiencing a deep crisis such as illness, disability, addictions or loneliness it is crucial to rebuild their sense of human dignity and to discover their life goals in the context of a personal vocation from God. ${ }^{40}$ Person experiencing excessive existential stagnation (e.g. seniors, widowers, people in depression and fear) should be motivated to common activities such as charity work, voluntary service in a parish community or in other places. Taking up precise and intentional tasks is one of the factors which reduce pathological grief or similar states. ${ }^{41}$ For people who come from broken families or who are building non-sacramental bonds it will be effective to lead them through the Church's teaching about the virtue of love, helping them understand proper matrimony and family relations. ${ }^{42}$ Whatever the community, the basis of formation should-always be the analysis of Holy Scripture, still unknown and unpopular among the Polish Catholics. A report from 2018 shows that merely $19 \%$ of Poles only read the Bible a minimum of once a year. Among people who declare regular religious practice this percentage increases to twice the percentage. ${ }^{43}$ The Word of God is not only neutral information the Creator but primarily it is alive, actual and the most adequate recommendation necessary to improvement the quality of a spiritual man's condition. It ist he space of God's true revelation to man and that is why it's proclamation is an essential requirement for pastoral animation. ${ }^{44}$ The stable formation for members of pastoral communities addressed at persons who are subject of these new social categories should be adjusted thematically and should be complemented by a retreat which allows a moment of acknowledging one's

40. Słomka, Działanie Boga w świecie. Analiza filozoficzna, Lublin 2018, Wydawnictwo KUL, pp. 25-27.

${ }^{41}$ J. Dziedzic, Żałoba po śmierci Jana Pawła II. Analiza ilościowa i jakościowa Księgi kondolencyjnej >>Internauci w hołdzie papieżowi Janowi Pawłowi $I I<<$, Kraków 2009, wyd. PAT, pp. $79-80$.

M. Brzeziński, Pastoral care of the family as ministry for marriage and the family, „Studia Teologiczne Idźcie i Głoście” 34 (2016), pp. 163-177.

43 http://imas.pl/wp-content/uploads/2018/04/Raport_IMAS_Jak_czytamy_Pismo_ Swiete_2018_04_full.pdf (18.03.2020).

${ }^{44}$ Benedykt XVI, Verbum Domini, Poznań 2010, wyd. Pallotinum, no. 6, 73. 
spiritual development throughout the journey and choosing a proper direction for further time of getting closer to God. ${ }^{45}$

Over a long-term special pastoral action for people who are affected by contemporary social problems, based on a self-help groups, allows one to formulate a programme for pastoral work appropriate for different kinds of communities. In each form of pastoral work it is necessary to ensure the presence of three foundations: a service of love (diaconia), a service of word (martyria) and a service of the sacraments (leitourgia), which completely build a community gathered around God (koinonia). ${ }^{46}$

\section{A place for pastoral communities based on a model of self-help groups in the Church structure}

The equal status of members of pastoral communities based on a self-help groups and the limited role of leaders means that the constant presence of priests is not always necessary. Lay people, by the power of the sacrament of holy Baptism are endowed with the triple office of Jesus Christ too. The representatives of lay as well fulfil prophet mission which occurs in indication of God. Lay persons not only have a right to take up pastoral work but they are obliged to it. It happens sometimes through personal faith testimony, at other times in engaging in mercy work or missionary activity understood as teaching about God. ${ }^{47}$ The Catholic Church in Poland, wanting to keep its vitality, needs to be increasingly more open to lay activity engaged in different religious movements, which is given the support and trust by the priests and as long as there is and the proper shaping of attitudes of those who can take responsibility for pastoral activity. Lay people themselves should remember that they are tools of the Church and they should move away from any spirit of unhealthy rivalry or temptation of particularization related to the re-evaluation of small groups in relation to the parish community. Finally, well formulated formation,

\footnotetext{
45 W. M. Nowak, Pustynia. Biblijne miejsce spotkania z Bogiem, Kraków 2018, wyd. Erem Ojców Kamedułów, pp. 3-18.

${ }^{46}$ W. Kasper, Bewahren oder Verändern?, in: U. Struppe, J. Weismayer (eds.), Öffnung zum Heute. Die Kirche nach dem Konzil, Insbruck 1991, Tyrolia, p. 131.

47 Jan Paweł II, Christiafideles laici, Wrocław 2017, wyd. TUM, no. 14-16.
} 
as a part of special pastoral care should lead to open to normal means offered by the Church in parishes. ${ }^{48}$

Communities based on a self-help model don't have to be assigned to be a parish-based. It is commonly observed that persons tend to seek and choose the churches and communities according to their personal liking and not according to an administrative affiliation. ${ }^{49}$ Apart from that, some communities functioning in the discussed paradigm will need the proper level of privacy which in parishes, especially in the smaller ones, cannot be possible on account of the closer social bonds of parishioners. It is to be expected that at the beginning of such a ministry of communities there will not be high numbers of persons willing to participate in the communities. The next severe problem for the Church which in next years will get stronger is the decrease of the number of priests active pastorally. Taking into consideration these problems it can be assumed that the most proper level in the Church structure in Poland for these kind of communities is the deanery or the area of a few adjacent deaneries (especially in the case of densely habituated areas such as big cities). Such pastoral support groups would have the appropriate structure depending on the specific problems named above and could involve one priest from the surrounding.

Lay people can fulfil apostolic activities in many ways. They are also vocated by God to do so whatever evangelization activity the Church commits them to, especially in places where there is a lack of priests. ${ }^{50}$ Apart from that it is difficult to imagine at this moment any pastoral work in the Church in Poland without any participation of priests. In the case where the priest has, at his disposal, opportunities of stable participation in pastoral self-help communities he should serve as one of the equal members of the group. For proper spiritual assistance to other people it could be necessary for priests to broaden their competence through their private spiritual formation or gain knowledge in the topic of social phenomenon which affects the faithful belonging to the particular community. ${ }^{51}$

A motivating factor to participation in pastoral self-help communities is aspecific situation common to the faithful emerging from the sudden social

${ }^{48}$ D. Lipiec, Apostolstwo świeckich w parafii, „Roczniki Pastoralno-Katechetyczne” 1 (2009) 56 , pp. $45-56$.

${ }^{49}$ K. Rosenkiewicz, Śródmiejskie wędrówki wiernych (churching) jako nowa perspektywa badań życia miasta, „Biuletyn KPZK PAN” 271 (2018), pp. 125-150.

50 Sobór Watykanski II, Apostolorum actuositatem, in: M. Przybył (ed.), Sobór Watykański II. Konstytucje, dekrety, deklaracje, Poznań 2002, wyd. Pallotinum, no. 3.

${ }^{51}$ Jan Paweł II, Pastores dabo vobis, Wrocław 1995, wyd. TUM, no. 70-81. 
changes occurring in the contemporary world. However, such self-help communities offer an opportunity of spiritual development to people who don't go through extremely difficult experiences e.g. mothers bringing up children in homes, seniors, people of science and culture, women, and men and others. These kinds of groups can be opened to people living in a given area but not having contact with each other every day. That is why it is important to communicate the presence of these communities in the parishes in the form of announcements and through mass media. Similar groups could be present in the parish or close to it. An example of pastoral work are groups for infertile couples „Abraham and Sarah" established for since a few years in Cracow

and gradually spread into a national polish association. ${ }^{52}$ Other examples are the community "Wspólnota Wojowników" (the Community of Warriors) forming men by regular work taking into account the specificity of their vocation to the Church life, ${ }^{53}$ and "Ubogacona" ("Enriched") which is a project for women also taking into consideration the specificity of their vocation to the Church life. ${ }^{54}$ These are only three chosen examples from the whole mosaic of different movements and communities that developed in the Catholic Church in Poland. Most often they arise as a grass roots initiative of lay people and priests participating in them as one of the members or Church assistants.

\section{Conclusion}

This article has presented the shape of the contemporary changing social situation, examples of new problems touching different categories of people, the genesis and conditions of working in self-help groups and the principles which can be used as a basis for building new kinds of pastoral work models in a paradigm of self-help communities. It constitutes one of the opportunities of the Church's response to the developing needs arising from the changing conditions in the world. In spite of the presence and development of new pastoral initiatives, the Church needs a reflection on the topic of changes which are arising in society and the needs which are generated in connection with them. The example of a long and rich tradition of the presence of the Church by sobriety

\footnotetext{
52 https://abrahamisara.pl/stowarzyszenie/o-nas/ (19.03.2020).

53 https://odwazni.pl/pl/o-nas (19.03.2020).

54 https://ubogacona.pl/ (19.03.2019).
} 
movements, especially Anonymous Alcoholics in Poland, shows that is possible to co-operate in a different way. Priests can now accompany those who take the internal formation in different communities, sometimes on account of the spiritual development itself and sometimes while work taking up in the direction in personal changes. The institutional Church should not only answer to initiatives of lay faithful but should also build new communities as an adequate response to conditions which emerge from social changes taking into consideration the staffing levels due to the decline of vocation to priesthood. The people to be targeted first could always be people in crisis, but apart from them there are many people searching for a good relation with God in different circumstances of their lives.

\section{Bibliography}

Biel R., Duszpasterstwo w kontekście paradygmatów czasu przełomu, in: R. Chałupniak, J. Kostorz (eds.), Współczesne wyzwania teologii pastoralnej, Opole 2016, wyd. Wydziału Teologicznego UO, pp. 67-76.

Brzeziński M., Pastoral care of the family as ministry for marriage and the family, "Studia Teologiczne Idźcie I Głoście” 34 (2016), pp. 163-177.

Davies C., Carter J. C., Compulsive overeating as an addiction disorder. A review of theory and evidence, "Appetite" 53 (2009) 1, pp. 1-8.

Wojtyniak B., Goryński P., Sytuacja zdrowotna ludności Polski i jej uwarunkowania, Warszawa 2008, wyd. Państwowy Zakład Higieny.

Dziedzic J., Żałoba po śmierci Jana Pawła II. Analiza ilościowa i jakościowa Księgi kondolencyjnej >>Internauci w hołdzie papieżowi Janowi Pawłowi $I I<<$, Kraków 2009, wyd. PAT.

Eliason M., Amodia D. S., Cano C., Spirituality and Alcohol and Other Drug Treatment: The Intersection with Culture, "Alcoholism Treatment Quarterly" 24 (3) (2006), pp. 121-141.

Firlit E., Wspólnotowy wymiar religijności, in: L. Adamczuk, E. Firlit, W. Zdaniewicz (eds.), Postawy społeczno-religijne Polaków 1991-2012, Warszawa 2013, wyd. Instytut Statystki Kościoła Katolickiego, pp. 133-146.

Jan Paweł II, Christifideles laici, Wrocław 2017, wyd. TUM.

Kasper W., Bewahren oder Verändern?, in: U. Struppe, J. Weismayer (eds.), Öffnung zum Heute. Die Kirche nach dem Konzil, Insbruck 1991, Tyrolia, pp. 109-132.

Koch K., Die Kirche Gottes, Trier 2007, Paulinus Verlag.

Lipiec D., Apostolstwo świeckich w parafii, Roczniki Pastoralno-Katechetyczne" 1 (2009) 56 , pp. 45-56. 
Mariański J., Praktyki religijne w Polsce w procesie przemian, in: L. Adamczuk, E. Firlit, W. Zdaniewicz (eds.), Postawy społeczno-religijne Polaków 1991-2012, Warszawa 2013, wyd. Instytut Statystki Kościoła Katolickiego, pp. 88-107.

Mariański J., Religia i moralność w świadomości Polaków - analiza socjologiczna, „Zeszyty Naukowe KUL" 57 (2014) nr 4 (228), pp. 67-91.

Pawłowska B., „Polak-katolik” - czyli o religijności współczesnych Polaków, „Władza Sądzenia" 6 (2015) 1, pp. 77-92.

Pekarskiene I., Susniene R., The Assessment of the Manifestation of Economic Globalization: The International Trade Factor, "Procedia - Social and Behavioral Sciences" 156 (2014), pp. 392-397.

Rosenkiewicz K., Śródmiejskie wędrówki wiernych (churching) jako nowa perspektywa badań życia miasta, „Biuletyn KPZK PAN” 271 (2018), p. 125-150.

Sadłon W., Differentiation, polarization and religious change in Poland at the turn of 20th and 21st century, „The Religious Studies Review” 262 (2016) 4, pp. 25-42.

Sobór Watykanski II, Apostolorum actuositatem, in: M. Przybył (ed.), Sobór Watykański II. Konstytucje, dekrety, deklaracje, Poznań 2002, wyd. Pallotinum.

Sobór Watykański II, Konstytucja Duszpasterska o Kościele w świecie współczesnym Gaudium et spes, Wrocław 2005, wyd. TUM.

Willoughby B.J., Carroll J.S., Busby D.M., The different effects of "living together": Determining and comparing types of cohabiting couples, "Journal of Social and Personal Relationships" 29 (3) (2011), pp. 397-419.

Wnuk M., Duchowy charakter Programu Dwunastu Kroków a jakość życia Anonimowych Alkoholików, „Alkoholizm i Narkomania” 20 (2007) 3, pp. 289-301. 